\title{
The current place of direct oral anticoagulants in the prevention/treatment of venous thromboembolism
}

\author{
Maja Tomić \\ University of Belgrade - Faculty of Pharmacy, Department of Pharmacology, \\ Vojvode Stepe 450, 11221 Belgrade, Serbia \\ Corresponding author: Maja Tomić, e-mail: majat@pharmacy.bg.ac.rs
}

\begin{abstract}
Summary
Venous thromboembolism (VTE; includes deep venous thrombosis, DVT, and pulmonary embolism, PE) represents the third most common acute cardiovascular syndrome. Contemporary VTE management comprises primary prevention in high-risk patients, treatment of established VTE, and prevention of its recurrence (secondary prevention). Anticoagulants are the basis of VTE pharmacological prophylaxis and treatment. For several decades, parenteral (heparin and low-molecular-weight heparins, LMWHs) and oral anticoagulants (vitamin K antagonists, VKAs) have been the cornerstone of VTE prevention/treatment. The introduction of direct oral anticoagulants (DOACs: thrombin inhibitor dabigatran and Xa inhibitors rivaroxaban, apixaban, edoxaban, and betrixaban) markedly improved the management of VTE by overcoming many disadvantages of conventional anticoagulants. For primary VTE prevention in patients after total hip/knee arthroplasty, rivaroxaban, apixaban, and dabigatran are preferred over LMWHs, due to comparable efficacy and safety, but favourable acceptability (avoided everyday injections). In other high-risk populations (other surgical patients, acutely ill medical patients), LMWHs are still the recommended option. Betrixaban is currently the only DOAC approved for VTE prophylaxis in medically ill patients during and after hospitalization. For acute VTE treatment and secondary prevention, DOACs (rivaroxaban, apixaban, edoxaban, and dabigatran) are recommended as the first-line therapy in the general population. DOACs proved to be similarly effective but safer than VKAs. In some specific populations, DOACs also seem to be advantageous over conventional treatment (patients with renal impairment, elderly, long-term secondary prevention in cancer patients). Currently, there is no data from randomized head-to-head comparative studies between the DOAC classes or representatives so the choice is made mainly according to patient characteristics and pharmacokinetic properties of the drug.
\end{abstract}

Keywords: direct oral anticoagulants (DOACs), venous thromboembolism (VTE), deep vein thrombosis (DVT), pulmonary embolism (PE) 


\section{Introduction}

Venous thromboembolism (VTE), with an incidence of 131 and 123 per 100000 person-years in Europe and the USA, respectively, and more than 10 million people globally $(1,2)$, represents the third most common acute cardiovascular syndrome (after myocardial infarction and stroke) (3). In the majority of cases, it presents as deep venous thrombosis (DVT) and in 30-40\% as pulmonary embolism (PE), with or without DVT (1). Both manifestations are the result of the same pathological process (i.e. activation of the coagulation cascade in the absence of bleeding). Thus, they are considered as one clinical entity. Signs and symptoms of DVT of the legs comprise swelling or pitting edema, redness, tenderness/pain, a "palpable cord", a feeling of warmth and heaviness in the affected limb, and the presence of collateral superficial veins. Clinical manifestations of PE include sudden onset of dyspnea, chest pain, dizziness or syncope (due to hypotension/shock), hemoptysis, tachycardia, tachypnea, and in some patients it can be presented as sudden death. Both DVT and PE can be asymptomatic. As signs and symptoms are unreliable, the diagnosis is based on the estimation of the likelihood of DVT and PE by using the clinical scoring criteria (e.g. Wells score), and plasma D-dimer testing. In patients with low clinical probability score, the diagnosis of VTE can be ruled out solely by a negative result of the D-dimer test. In the remaining patients, the diagnosis of DVT and PE is usually made with compression ultrasound and chest computed tomography, respectively $(3,4)$. Despite the substantial advances in DVT/PE treatment, up to half of the patients suffer chronic complications after the completion of treatment. These include post-thrombotic syndrome (swelling and aching in the leg particularly after long standing due to insufficiency of vein valves), pulmonary hypertension, chronic dyspnoea, and limited exercise capacity $(3,4,5)$.

Keeping in mind the high and increasing incidence rate, substantial morbidity, and mortality and huge socioeconomic burden $(1,3)$, improving the way of fighting VTE is one of the most important goals of modern pharmacotherapy. Contemporary management of VTE is directed toward: 1) Recognizing patients at risk of developing VTE, estimating the risk level, and undertaking primary prevention measures; 2) Treatment of established VTE and prevention of recurrent VTE (secondary prevention).

Anticoagulant drugs (i.e. drugs that reduce the formation of fibrin) are the foundation of VTE pharmacological prophylaxis and treatment. For several decades, conventional anticoagulants comprising parenteral (unfractionated heparin - UFH, lowmolecular-weight heparins - LMWHs and fondaparinux) and oral anticoagulants (vitamin K antagonists - VKAs: warfarin and acenocoumarol) have been the cornerstone of VTE prevention/treatment $(1,4)$. The introduction of direct oral anticoagulants (DOACs) - thrombin (factor IIa) inhibitor dabigatran and factor Xa inhibitors rivaroxaban, apixaban, edoxaban, and betrixaban, over the past 12 years, has brought a marked improvement in the management of VTE by overcoming many of the shortcomings associated with conventional anticoagulant medications. DOAC's 
advantages include faster onset/offset of action, more predictable anticoagulant effect, less need for the effect monitoring and fewer food/drug interactions. This article considers the current place of DOACs in the prevention/treatment of VTE, taking into account current clinical guidelines and the available evidence on their efficacy and safety from clinical studies, meta-analysis, and "real-life" data.

\section{DOACs in the primary prevention of VTE}

Although no predisposing risk factors can be identified in approximately one third to one half of patients, VTE is usually associated with various transient or persistent factors that act additively/synergistically to cause increased propensity of blood to coagulate (hypercoagulability), decreased blood flow (stasis), or injury of the blood vessel wall (Table I).

Table I VTE risk factors $(3,6,7)$

Tabela I Faktori rizika za VTE $(3,6,7)$

\begin{tabular}{|c|c|c|c|}
\hline \multicolumn{3}{|c|}{ Clinical/environmental factors } & Heritable factors \\
\hline Hypercoagulability & $\begin{array}{l}\text { Venous } \\
\text { stasis/immobilization }\end{array}$ & $\begin{array}{l}\text { Vascular wall } \\
\text { damage }\end{array}$ & Hypercoagulability \\
\hline $\begin{array}{l}\text { Advanced age } \\
\text { Active cancer } \\
\text { Oestrogen therapy (oral } \\
\text { contraceptives; hormone } \\
\text { replacement therapy) } \\
\text { Pregnancy/puerperium } \\
\text { VTE history } \\
\text { Autoimmune/chronic } \\
\text { inflammatory diseases } \\
\text { Obesity }\end{array}$ & $\begin{array}{l}\text { Hospitalization due to } \\
\text { acute medical illness } \\
\text { Nursing home residence } \\
\text { Long-haul travels } \\
\text { ( }>4 \text { hours) } \\
\text { Paresis/paralysis }\end{array}$ & $\begin{array}{l}\text { Surgery } \\
\text { Trauma/fracture } \\
\text { Pacemaker } \\
\text { Central venous } \\
\text { catheter }\end{array}$ & $\begin{array}{l}\text { Factor V Leiden } \\
\text { Antithrombin/ } \\
\text { protein } \mathrm{C} / \\
\text { protein S deficiency } \\
\text { Non-0 blood group }\end{array}$ \\
\hline
\end{tabular}

Strong risk factors for VTE include surgery (orthopedic and non-orthopedic), immobilization, cancer, previous VTE, and known thrombophilic condition $(3,7,8,9)$. Several risk factor scoring models are available to clinicians for assessing the risk of VTE as well as the risk of bleeding for each patient individually. Pharmacologic prophylaxis is considered when the thrombotic risk is estimated to be greater than the risk of bleeding. That is often the case in surgical and acutely ill medical patients hospitalized for various reasons other than surgery. Table II displays an example of a clinical risk assessment model for acutely ill medical patients (Padua Prediction Score risk assessment). Risk factors for this heterogeneous population include intrinsic factors (such as age above 70 
years, previous VTE, known thrombophilia, and illnesses, such as cancer, heart failure, respiratory failure, acute infection, and rheumatic disorder), and extrinsic factors (such as immobilization for 3 days or more and hormonal medications) $(8,9)$. In this model, the high risk of VTE is defined by a cumulative score $\geq$ of 4 points. In high-risk VTE acutely ill medical patients with acceptable bleeding risk, pharmacological VTE prophylaxis is indicated. In those with unacceptable bleeding risk, mechanical prophylaxis is appropriate (by use of graduated compression stockings or a device for intermittent pneumatic compression) (9).

Table II Padua risk assessment model in hospitalized medical patients $(8,9)$

Tabela II Padua klinički model za procenu nivoa rizika u pacijenata hospitalizovanih zbog različitih oboljenja $(8,9)$

\begin{tabular}{|l|c|}
\hline Risk factor & points \\
\hline Active cancer* & 3 \\
\hline Reduced mobility** & 3 \\
\hline Previous VTE & 3 \\
\hline Known thrombophilic condition*** & 3 \\
\hline Trauma and/or surgery within previous month & 2 \\
\hline Age $\geq 70$ years & 1 \\
\hline Heart and/or respiratory failure & 1 \\
\hline Acute myocardial infarction or ischemic stroke & 1 \\
\hline Acute infection and/or rheumatologic disorder & 1 \\
\hline Obesity (BMI $\geq 30$ ) & 1 \\
\hline Ongoing hormonal treatment & 1 \\
\hline
\end{tabular}

* local or distant metastases and/or chemotherapy or radiotherapy performed within previous 6 months

** anticipated bed rest with bathroom privileges for at least 3 days

*** defects of antithrombin, protein C or S, factor V Leiden, G20210A prothrombin mutation and antiphospholipid syndrome

Parenteral anticoagulants (low-dose LMWH or UFH) are the most commonly used for VTE prevention in hospitalized patients. When prolonged prophylaxis is required, switching to VKA is the standard practice, although the use of aspirin is also an option in some subgroups, according to the current guidelines $(4,10,11,12)$. Specifically, National Institute for Health and Care Excellence (NICE) guidelines for reducing VTE risk after orthopaedic surgery state that aspirin could be an option for VTE prevention after elective 
knee ( 75 or $150 \mathrm{mg}$ for 14 days) or hip replacement ( 75 or $100 \mathrm{mg}$, introduced after 10 day administration od LMWH, and administered for a further 28 days) (12).

In patients after total hip or knee arthroplasty with favourable benefit/risk ratio for thromboprophylaxis, the latest American Society of Hematology (ASH) guidelines (2019) suggest the use of DOACs over LMWHs (11). This recommendation arose from the review of 37 clinical studies evaluating the efficacy and safety of DOACs in VTE prevention in patients undergoing elective hip/knee replacement in comparison with conventional prophylaxis, mostly LMWHs. The analysis suggested that DOACs are comparable with LMWHs in reducing symptomatic DVT and PE and mortality, as well as the incidence of major bleeding. The recommendation in favour of DOACs is based on equity, acceptability, and feasibility, particularly for out-of-hospital prevention (which is routine after total knee/hip arthroplasty), where instead of everyday injections of LMWH, patients receive oral medication. The dose regimens for DOACs approved for VTE prevention after total hip/knee arthroplasty (rivaroxaban, apixaban, dabigatran), and the recommended duration of prophylaxis are displayed in Table III.

Table III The dosage regimens of DOACs in the primary prevention of VTE $(4,12,13,14,15)$

Tabela III Režim doziranja DOAK-a u primarnoj prevenciji VTE $(4,12,13,14,15)$

\begin{tabular}{|l|l|}
\hline \multicolumn{2}{|l|}{ Primary prevention of VTE in patients after total knee or hip replacement surgery } \\
\hline Rivaroxaban & $\begin{array}{l}10 \mathrm{mg}, \text { once a day (initiated 6-10 hours postoperatively) } \\
\text { duration: } 5 \text { weeks after hip, 12-14 days after knee replacement }\end{array}$ \\
\hline Apixaban & $\begin{array}{l}2.5 \mathrm{mg}, \text { twice a day (initiated 12-24 hours postoperatively) } \\
\text { duration: } 32-38 \text { days after hip, 10-14 days after knee replacement }\end{array}$ \\
\hline Dabigatran & $\begin{array}{l}110 \mathrm{mg}\left(75 \mathrm{mg}^{*}\right) \text { on the first day (initiated 1-4 hours postoperatively), then } 220 \mathrm{mg} \\
(150 \mathrm{mg}), \text { once a day } \\
\text { duration: } 28-35 \text { days after hip, 10 days after knee replacement }\end{array}$ \\
\hline Primary prevention of VTE in medically ill patients during and after hospitalization \\
\hline Betrixaban & $\begin{array}{l}10 \mathrm{mg}, \text { once a day } \\
\text { duration: } 35-42 \text { days }\end{array}$ \\
\hline
\end{tabular}

* Patients with creatinine clearance $(\mathrm{CrCl}) 30-50 \mathrm{~mL} / \mathrm{min}$; $\geq 75$ years; or on therapy with P-glycoprotein inhibitors

The ASH (2019) also performed indirect comparisons and did not detect any differences between anti-IIa and anti-Xa agents, neither between the individual DOAC representatives (11). While awaiting the results from direct comparative ("head to head") 
clinical trials, indirect comparisons, and cohort trials indicate that differences might exist. In the recent, first prospective cohort comparative study on efficacy and safety of 3 DOACs (rivaroxaban, dabigatran, and apixaban) in $2431 \mathrm{hip} / \mathrm{knee}$ arthroplasty patients (16) the authors suggested that rivaroxaban may have superior efficacy over apixaban and dabigatran while no difference was observed in major bleeding incidence among these agents.

ASH (2018) guidelines for VTE prophylaxis in acutely ill medical patients recommend LMWH over DOAC for VTE prophylaxis (9). This recommendation relies on the analysis of 3 randomized clinical studies comparing the efficacy and safety of standard (6-14 day) course of inpatient treatment with LMWH (enoxaparin) with a course of extended (30-42 days) treatment with rivaroxaban (MAGELLAN) (17), apixaban (ADOPT) (18), or betrixaban (APEX) (19). DOACs were similarly effective as LMWH in preventing VTE-related mortality, symptomatic DVT, and nonfatal PE, but carried an increased risk for major bleeding. The dose regimen of betrixaban, the only approved DOAC for this indication, is shown in Table III.

\section{DOACs in the treatment of acute VTE and secondary prevention}

Untreated VTE is associated with early recurrences (in 29\% of patients) and death (in $26 \%$ of patients). Therefore, anticoagulant treatment should start promptly, assuming the absence of absolute contraindications (1). Anticoagulation aims to suppress clot enlargement, to reduce the risk of embolization and chronic complications, to lessen symptoms, and to prevent VTE recurrence $(1,4)$. Before the introduction of DOACs, the standard VTE regimen consisted of initial anticoagulation with a parenteral drug (most commonly LMWH) and introduction of VKA (most commonly warfarin), at the same time with parenteral anticoagulant or a few days later. In this regimen, parenteral anticoagulant, since it acts rapidly, "bridges" the time required for establishing an adequate anticoagulant effect of VKA, which is confirmed by a stable target international normalized ratio (INR), in two consecutive measurements, at least 1 day apart. Then the parenteral anticoagulant is stopped (after at least 5 days of treatment) and VKA is continued as monotherapy $(5,9)$. For treating VTE, DOACs were evaluated in two different regimens. The sequential regimen comprises an initial parenteral therapy (commonly with LMWH) switched after 5-7 days to dabigatran or edoxaban. In the single-drug regimen, the therapy is initiated with rivaroxaban or apixaban with a 3-week or 1-week loading dose, respectively, followed by a maintenance dose (Table IV). The duration of anticoagulant treatment, regardless of regimen, is 3-6 months for patients with VTE associated with the presence of provoking factors. Extended anticoagulation (beyond 6 months) is considered in patients with idiopathic, unprovoked VTE and patients with cancer-associated VTE $(2,3,4,20,21,22,23)$.

In patients with extensive DVT, the dissolution of the clot with the catheter-directed application of fibrinolytic is usually performed; in those with PE who deteriorate 
hemodynamically, systemic or catheter-directed thrombolysis or surgical embolectomy are the rescue options $(4,20)$. In this, a minor proportion of patients with the most severe clinical presentations, initial anticoagulation with UFH/LMWH is the preferred option, due to the lack of safety data from controlled clinical trials on the use of DOACs and fibrinolytic drugs in parallel. The introduction of DOAC should probably be postponed for at least 1 day after thrombolysis or mechanical reperfusion (1).

Table IV DOAC dosage regimens in the treatment and secondary prevention of VTE $(1,3,4,5,14,15)$

Tabela IV Režim doziranja DOAK-a u terapiji i sekundarnoj prevenciji VTE $(1,3,4,5,14,15)$

\begin{tabular}{|c|c|l|}
\hline \multirow{2}{*}{ Regimen type } & \multicolumn{1}{|c|}{ DOAC } & \multicolumn{1}{c|}{ Dosages and duration } \\
\hline \multirow{3}{*}{ Single-drug } & \multirow{2}{*}{ Rivaroxaban } & $\begin{array}{l}15 \mathrm{mg}, \text { twice a day (days } 1-21) \\
20 \mathrm{mg}, \text { once a day (day 22 to 3-6 months) } \\
10-20 \mathrm{mg}, \text { once a day ( }>6 \mathrm{months})\end{array}$ \\
\cline { 2 - 3 } & \multirow{2}{*}{ Apixaban } & $\begin{array}{l}10 \mathrm{mg}, \text { twice a day (days } 1-7) \\
5 \mathrm{mg}, \text { twice a day (days 7 to } \geq 3 \text { months) }\end{array}$ \\
\hline \multirow{2}{*}{ Sequential* } & Edoxaban & $60 \mathrm{mg} * *$, once a day (days 6-8 to $\geq 3 \mathrm{months})$ \\
\cline { 2 - 3 } & Dabigatran & $150 \mathrm{mg} * * *$, twice a day (days 6-8 to $\geq 3$ months) \\
\hline
\end{tabular}

* Treatment is initiated with the parenteral anticoagulant, for the first 5-7 days; when the parenteral drug is stopped, the DOAC is introduced on the next day.

** Doses are reduced to $30 \mathrm{mg}$ in patients with body weight $<61 \mathrm{~kg}$; creatinine clearance $\leq 50 \mathrm{~mL} / \mathrm{min}$; concomitant potent P-glycoprotein inhibitors

*** Doses are reduced to: $110-150 \mathrm{mg}$ in age $75-79$ years or moderate renal impairment; and to $110 \mathrm{mg}$ in age $\geq 80$ years or concomitant P-glycoprotein inhibitors

In the current guidelines, including those from relevant associations in Europe, the United States, Australia, and New Zealand, DOACs are recommended as the first-line therapy for acute VTE treatment and secondary prevention in the general population $(2,20,21)$. These recommendations have emerged from the results of 6 phase III randomized clinical trials which compared acute treatment with DOACs to standard anticoagulation treatment in a total of 27023 patients with acute VTE. Studies RECOVER (24) and RE-COVER II (25) evaluated dabigatran, EINSTEIN-DVT (26) and EINSTEIN-PE (27) evaluated rivaroxaban, AMPLIFY evaluated apixaban (28) and Hokusai-VTE evaluated edoxaban (29). A meta-analysis of these trials has indicated that 
each of the examined DOAC was non-inferior to standard treatment as recurrent VTE occurred in $2.0 \%$ of patients receiving DOACs and in $2.2 \%$ of those receiving VKAs. DOAC therapy was associated with a 39\% relative reduction in major bleeding (30). Thus, DOACs proved to be similarly effective but safer than VKAs in the treatment of acute VTE and secondary prevention.

Currently, there is no data from randomized "head to head" comparative studies between the sequential and single-drug regimen, nor between individual DOAC representatives used for VTE treatment. Only the indirect comparison data are available so far. In the systematic literature review of network meta-analysis of studies on VTE acute treatment, the majority of evidence points to a significant reduction in risk of major and clinically relevant bleeding with apixaban compared to dabigatran and edoxaban. In the extended treatment setting, there was a reduction of risk of major bleeding with apixaban compared to rivaroxaban or dabigatran (31). Another recent systematic review of 16 randomized controlled trials concluded that there was no significant difference between the efficacy and safety of individual DOACs in the acute VTE treatment (the tendency toward the lowest risk of recurrent VTE was observed with rivaroxaban and toward the lowest risk of major bleeding with apixaban) (32). The phase 4 randomized trial comparing apixaban and rivaroxaban for patients with acute VTE is ongoing $(1,5)$.

Data about efficacy/safety of DOACs in VTE treatment in specific populations of patients have been obtained from sub-analyses of phase 3 studies and/or by performing additional studies $(22,30,33)$. DOACs were non-inferior and safer compared to standard treatment in patients with renal impairment (i.e. with creatinine clearance - $\mathrm{CrCl}$ in range of 50 to $39 \mathrm{~mL} /$ minute) (30). European Medical Agency recommends dose adjustments for dabigatran in patients aged $\geq 80$ years or those $75-80$ years if $\mathrm{CrCl}$ is between 50 and $30 \mathrm{~mL} / \mathrm{min}$ and for rivaroxaban if $\mathrm{CrCl}$ is between 50 and $30 \mathrm{~mL} / \mathrm{min}$. It is important to note that no dose adjustments were done in clinical trials evaluating DOACs in patients with acute VTE (except for edoxaban, Table 3), so the absence of clinical data for reduced dose regimens in patients with renal failure give rise to some concern about the risk of potentially ineffective VTE treatment (1). Current International Initiative on Thrombosis and Cancer (ITAC, 2019) and American Society of Clinical Oncology (ASCO, 2019) clinical practice guidelines recommend LMWHs for the initial treatment of established VTE in patients with cancer $(22,23)$. Rivaroxaban or edoxaban regimens (Table 3 ) can be alternatively considered for the initial treatment, in patients without a high risk of gastrointestinal (GI) bleeding (i.e. patients with GI cancer, particularly in the upper GI tract). As patients with cancer-associated VTE are candidates for extended anticoagulant therapy (for at least 6 months), daily subcutaneous injections of LMWHs can be burdensome and uncomfortable for them. To possibly overcome this problem, randomized studies with DOACs in cancer-associated VTE were performed and demonstrated improved efficacy of edoxaban and rivaroxaban compared with LMWH on the one hand, and an increased incidence of bleeding complications (mainly GI), on 
another (34,35). ITAC 2019 and ASCO 2019 guidelines recommend edoxaban or rivaroxaban for long-term anticoagulation in secondary prevention of VTE for patients with cancer, taking into account concomitant medications and comorbidities when choosing a therapy. In patients with GI malignancies, they should be used with caution $(22,23)$. Women represent a special population concerning DOACs safety. Post-hoc analysis of phase 3 studies pointed to increased risk of uterine bleeding with rivaroxaban and edoxaban, and the relative occurrence of vaginal bleeds was higher in apixabantreated than in warfarin-treated women $(36,37,38)$. It remains debatable whether these findings should discourage physicians from prescribing some of the DOACs in women. Concerning the ability of DOACs to pass through the placenta and transfer into breast milk, the data on reproductive toxicity from animal studies, and the absence of clinical data for human use, they are not recommended during pregnancy or lactation. LMWHs are the anticoagulants of choice in pregnant/lactating women $(1,20)$. Concerning elderly patients, post hoc analysis of phase 3 trials in patients older than 75 years showed that DOACs were more effective and safer than the standard VTE treatment (30). Very limited data is available for this subgroup. Comorbidities, concomitant therapies, and bleeding risk should be considered when choosing the appropriate VTE treatment (1).

\section{Conflicts of interest}

The author declared no conflicts of interest.

\section{References:}

1. Becattini C, Agnelli G. Acute treatment of venous thromboembolism. Blood. 2020;135(5):305-316.

2. Tran HA, Gibbs H, Merriman E, Curnow JL, Young L, Bennett A, et al. New guidelines from the Thrombosis and Haemostasis Society of Australia and New Zealand for the diagnosis and management of venous thromboembolism. Med J Aust. 2019;210(5):227-235.

3. Di Nisio M, van Es N, Büller HR. Deep vein thrombosis and pulmonary embolism. Lancet. 2016;388(10063):3060-3073.

4. Goldhaber SZ. Deep Venous Thrombosis and Pulmonary Thromboembolism. In: Jameson JL, Kasper DL, Longo DL, Fauci AS, Hauser SL, Loscalzo J, editors. Harrison's principles of internal medicine. $20^{\text {th }}$ ed. New York: McGraw-Hill Education; 2018. p. 1910-1917.

5. Duffett L, Castellucci LA, Forgie MA. Pulmonary embolism: update on management and controversies. BMJ. 2020;370:m2177. 
6. Bates SM, Ginsberg JS. Clinical practice. Treatment of deep-vein thrombosis. N Engl J Med. 2004;351(3):268-77.

7. Shirvanian S, Tapson VF. Venous thromboembolism: identifying patients at risk and establishing prophylaxis. Curr Med Res Opin. 2015;31(12):2297-2311.

8. Kahn SR, Lim W, Dunn AS, Cushman M, Dentali F, Akl EA, et al. Prevention of VTE in nonsurgical patients: Antithrombotic Therapy and Prevention of Thrombosis, 9th ed: American College of Chest Physicians Evidence-Based Clinical Practice Guidelines. Chest. 2012;141(2 Suppl):e195S-e226S.

9. Schünemann HJ, Cushman M, Burnett AE, Kahn SR, Beyer-Westendorf J, Spencer FA, et al. American Society of Hematology 2018 guidelines for management of venous thromboembolism: prophylaxis for hospitalized and nonhospitalized medical patients. Blood Adv. 2018;2(22):31983225.

10. Beyer-Westendorf J, Ageno W. Benefit-risk profile of non-vitamin K antagonist oral anticoagulants in the management of venous thromboembolism. Thromb Haemost. 2015;113(2):231-46.

11. Anderson DR, Morgano GP, Bennett C, Dentali F, Francis CW, Garcia DA, et al. American Society of Hematology 2019 guidelines for management of venous thromboembolism: prevention of venous thromboembolism in surgical hospitalized patients. Blood Adv. 2019;3(23):3898-3944.

12. The National Institute for Health and Care Excellence. [Internet]. [cited 2020 aug 19]. Available from: http://pathways.nice.org.uk/pathways/venous-thromboembolism

13. Miller KM, Brenner MJ. Betrixaban for Extended Venous Thromboembolism Prophylaxis in HighRisk Hospitalized Patients: Putting the APEX Results into Practice. Drugs. 2019;79(3):291-302.

14. Joint Formulary Committee. British National Formulary. 78. London: BMJ Group and Pharmaceutical Press; 2019.

15. Brayfield A. Martindale The Complete Drug Reference, 39th ed. London: Pharmaceutical Press; 2017.

16. Highcock AJ, As-Sultany M, Finley R, Donnachie NJ. A Prospective Cohort Comparative Study of Rivaroxaban, Dabigatran, and Apixaban Oral Thromboprophylaxis in 2431 Hip and Knee Arthroplasty Patients: Primary Efficacy Outcomes and Safety Profile. J Arthroplasty. 2020;S08835403(20)30676-8.

17. Cohen AT, Spiro TE, Büller HR, Haskell L, Hu D, Hull R, et al. Rivaroxaban for thromboprophylaxis in acutely ill medical patients. N Engl J Med. 2013;368(6):513-523.

18. Goldhaber SZ, Leizorovicz A, Kakkar AK, Haas SK, Geno Merli G, Knabb RM, et al. Apixaban versus enoxaparin for thromboprophylaxis in medically ill patients. $\mathrm{N}$ Engl $\mathrm{J}$ Med. 2011;365(23):2167-2177.

19. Cohen AT, Harrington RA, Goldhaber SZ, Hull RD, Wiens BL, Gold A et al. Extended thromboprophylaxis with betrixaban in acutely ill medical patients. N Engl J Med. 2016;375(6):53444. 
20. Konstantinides SV, Meyer G, Becattini C, Bueno H, Geersing GJ, Harjola VP et al. 2019 ESC Guidelines for the diagnosis and management of acute pulmonary embolism developed in collaboration with the European Respiratory Society (ERS): The Task Force for the diagnosis and management of acute pulmonary embolism of the European Society of Cardiology (ESC). Eur Respir J. 2019;54(3):1901647.

21. Kearon C. Diagnosis of suspected venous thromboembolism. Hematology Am Soc Hematol Educ Program. 2016;2016(1):397-403.

22. Farge D, Frere C, Connors JM, Ay C, Khorana AA, Munoz A, et al. 2019 international clinical practice guidelines for the treatment and prophylaxis of venous thromboembolism in patients with cancer. Lancet Oncol. 2019;20(10):e566-e581.

23. Key NS, Khorana AA, Kuderer NM, Bohlke K, Lee AYY, Arcelus JI, et al. Venous Thromboembolism Prophylaxis and Treatment in Patients With Cancer: ASCO Clinical Practice Guideline Update. J Clin Oncol. 2020;38(5):496-520.

24. Schulman S, Kearon C, Kakkar AK, Mismetti P, Schellong S, Eriksson H et al. Dabigatran versus warfarin in the treatment of acute venous thromboembolism. N Engl J Med. 2009; 361(24):23422352.

25. Schulman S, Kakkar AK, Goldhaber SZ, Schellong S, Eriksson H, Mismetti P et al. Treatment of acute venous thromboembolism with dabigatran or warfarin and pooled analysis. Circulation. 2014;129(7):764-772.

26. EINSTEIN Investigators, Bauersachs R, Berkowitz SD, Brenner B, Buller HR, Decousus H et al. Oral rivaroxaban for symptomatic venous thromboembolism. N Engl J Med. 2010;363(26):2499510.

27. EINSTEIN-PE Investigators; Büller HR, Prins MH, Lensin AWA, Decousus H, Jacobson BF et al. Oral rivaroxaban for the treatment of symptomatic pulmonary embolism. $\mathrm{N}$ Engl J Med. 2012;366(14):1287-97.

28. Agnelli G, Buller HR, Cohen A, Curto M, Gallus AS, Johnson M et al. Oral apixaban for the treatment of acute venous thromboembolism. N Engl J Med. 2013;369(9):799-808.

29. Hokusai-VTE Investigators; Büller HR, Décousus H, Grosso MA, Mercuri M, Middeldorp S, et al. Edoxaban versus warfarin for the treatment of symptomatic venous thromboembolism. N Engl J Med. 2013;369(15):1406-15.

30. Nick van Es, Coppens M, Schulman S, Middeldorp S, Büller HR. Direct oral anticoagulants compared with vitamin $\mathrm{K}$ antagonists for acute venous thromboembolism: evidence from phase 3 trials. Blood. 2014; 124(12):1968-75.

31. Cohen AT, Berger SE, Milenković D, Hill NR, Lister S. Anticoagulant selection for patients with VTE-Evidence from a systematic literature review of network meta-analyses. Pharmacol Res. 2019;143:166-177.

32. Li G, Zeng J, Zhang J, Thabane L. Comparative Effects Between Direct Oral Anticoagulants for Acute Venous Thromboembolism: Indirect Comparison From Randomized Controlled Trials. Front Med (Lausanne). 2020;7:280. 
33. Bavalia R, Middeldorp S, Weisser G, Espinola-Klein C. Treatment of Venous Thromboembolism in Special Populations with Direct Oral Anticoagulants. Thromb Haemost. 2020;120(6):899-911.

34. Raskob GE, van Es N, Verhamme P, Carrier M, Di Nisio M, Garcia D, et al. Edoxaban for the treatment of cancer-associated venous thromboembolism. N Engl J Med. 2018;378(7):615-624.

35. Young AM, Marshall A, Thirlwall J, Chapman O, Lokare A, Hill C, et al. Comparison of an oral factor Xa inhibitor with low molecular weight heparin in patients with cancer with venous thromboembolism: results of a randomized trial (SELECT-D). J Clin Oncol. 2018;36(20):2017-2023

36. Martinelli I, Lensing AW, Middeldorp S, et al. Recurrent venous thromboembolism and abnormal uterine bleeding with anticoagulant and hormone therapy use. Blood. 2016; 127(11):1417-1425.

37. Scheres L, Brekelmans M, Ageno W, Ay C, Büller HR, Eichinger S, et al. Abnormal vaginal bleeding in women of reproductive age treated with edoxaban or warfarin for venous thromboembolism: a post hoc analysis of the Hokusai-VTE study. BJOG. 2018;125(12):1581-1589.

38. Brekelmans MP, Scheres LJ, Bleker SM, Hutten BA, Timmermans A, Büller HR, et al. Abnormal vaginal bleeding in women with venous thromboembolism treated with apixaban or warfarin. Thromb Haemost. 2017;117(4):809-815. 


\title{
Mesto direktnih oralnih antikoagulansa u prevenciji/lečenju venskog tromboembolizma
}

\author{
Maja Tomić \\ Univerzitet u Beogradu - Farmaceutski fakultet, Katedra za farmakologiju, \\ Vojvode Stepe 450, 11221 Beograd, Srbija
}

Autor za korespondenciju: Maja Tomić, e-mail: majat@pharmacy.bg.ac.rs

\begin{abstract}
Kratak sadržaj
Venski tromboembolizam (VTE; uključuje duboku vensku trombozu, DVT i plućnu emboliju, PE) predstavlja treći najčešći akutni kardiovaskularni sindrom. Savremeno zbrinjavanje VTE uključuje primarnu prevenciju kod visokorizičnih pacijenata, lečenje uspostavljene VTE i prevenciju relapsa (sekundarna prevencija). Antikoagulansi su osnova farmakološke profilakse i lečenja VTE. Tokom nekoliko decenija su parenteralni (heparin i niskomolekularni heparini, LMWH) i oralni antikoagulansi (antagonisti vitamina K, VKA) bili kamen temeljac prevencije/lečenja VTE. Uvođenje direktnih oralnih antikoagulansa (DOAK: inhibitor trombina dabigatran i inhibitori Xa rivaroksaban, apiksaban, edoksaban i betriksaban) značajno je poboljšalo prevenciju i lečenje VTE prevazilaženjem mnogih nedostataka konvencionalnih antikoagulansa. Za primarnu prevenciju VTE kod pacijenata nakon totalne artroplastike kuka/kolena, rivaroksaban, apiksaban i dabigatran su u prednosti nad LMWH, zbog uporedive efikasnosti i bezbednosti, ali i bolje prihvatljivosti za pacijenta (izbegavanja svakodnevnih injekcija). U ostalim populacijama visokog rizika (drugi hirurški pacijenti, pacijenti sa različitim akutnim oboljenjima), LMWH su i dalje preporučena profilaksa. Betriksaban je trenutno jedini DOAK odobren za profilaksu VTE kod akutno bolesnih pacijenata tokom i nakon hospitalizacije. Za akutni tretman VTE i sekundarnu prevenciju, DOAK (rivaroksaban, apiksaban, edoksaban i dabigatran) se preporučuju kao prva linija terapije u opštoj populaciji. DOAK su se pokazali slično efikasni, ali bezbedniji od VKA. U nekim specifičnim populacijama pacijenata DOAK takođe imaju prednost u odnosu na konvencionalnu antikoagulantnu terapiju (pacijenti sa oštećenjem bubrega, starije osobe, dugotrajna sekundarna prevencija kod kancerskih pacijenata). Trenutno ne postoje podaci iz studija direktnog poređenja između klasa ili predstavnika DOAKa, tako da se izbor uglavnom vrši prema karakteristikama pacijenta i farmakokinetičkim osobinama leka.
\end{abstract}

Ključne reči: direktni oralni antikoagulansi (DOAK), venska tromboembolija (VTE), duboka venska tromboza (DVT), plućna embolija (PE) 